\title{
PROSES BERPIKIR SISWA SMK DALAM MENYELESAIKAN MASALAH MATEMATIKA DITINJAU DARI TIPE KEPRIBADIAN PHLEGMATIS
}

\author{
Rina Agustina $^{1}$, Nurul Farida ${ }^{2}$ \\ ${ }^{1,2}$ Pendidikan Matematika FKIP Universitas Muhammadiyah Metro \\ E-mail: aasyiqun1212@gmail.com ${ }^{1)}$ \\ nurulfarida.maniz@yahoo.com ${ }^{2)}$
}

\begin{abstract}
The aims of the research is to describe the thinking process at SMK students to solve matematic problems viewed from personality type phlegmatic. The research was a descriptive qualitative. The subjects of the research was students of class XI SMK Negeri 3 Metro. Technique analyzing of the data were: (1) classifying the, (2) presenting the data, and (3) concluding the data in each categories. The results of the research showed that thinking process for phlegmatic student: (a) understanding information and question, (b) devising solution, connecting the first equation with the planned solution (c) only using one way solution.
\end{abstract}

Keywords: thinking process, problem solving, personality type phlegmatis.

\section{PENDAHULUAN}

Matematika merupakan salah satu pelajaran yang mampu mengembangkan kreativitas siswa terutama dalam mengembangkan kreativitas berpikir seseorang. Hal ini dikarenakan dalam mempelajari matematika, siswa dituntut untuk dapat mengembangkan pola berpikir kritis, sistematis, rasional, dan obyektif. Menurut Dewiyani (2008), beberapa keterampilan yang dikenal dapat digunakan untuk meningkatkan kemampuan pemecahan masalah dalam matemarika adalah:

1. Memahami soal: memahami dan mengidentifikasi apa fakta atau informasi yang diberikan, apa yang ditanyakan, diminta untuk dicari, atau dibuktikan.

2. Memilih pendekatan atau strategi pemecahan: misalkan menggambarkan masalah dalam bentuk diagram, memilih dan menggunakan pengetahuan aljabar yang diketahui dan konsep yang relevan untuk membentuk kalimat matematika.

3. Menyelesaikan soal: melakukan operasi hitung secara benar dalam menerapkan strategi, untuk 


\section{mendapatkan solusi dari masalah.
4. Menafsirkan masalah: memperkirakan dan memeriksa kebenaran jawaban, dan apakah memberikan pemecahan terhadap masalah semula.

Rendahnya prestasi belajar matematika siswa kemungkinan tidak hanya disebabkan oleh pembelajaran yang kurang tepat. Tetapi juga dapat disebabkan oleh perbedaan tipe kepribadian yang dimiliki oleh setiap individu. Menurut Stagner (dalam Sukmadinata, 2004: 136), mengartikan kepribadian dalam dua macam. Pertama, kepribadian sebagai topeng (mask personality), yaitu kepribadian yang berpurapura, yang dibuat-buat, yang semu atau mengandung kepalsuan. Kedua, kepribadian sejati (real personality) yaitu kepribadian yang sesungguhnya, yang asli. Menurut Allport (dalam Sukmadinata, 2004: 136), kepribadian sebagai suatu yang terjalin dalam hubungan sosial, "Personality is the individual characteristis reactions to social stimuli and the quality of his adaptation to the social features of his environment".

Salah satu tipe kepribadian introvert yaitu tipe kepribadian plegmatis. Orang yang terlalu banyak Lympha (flegma) di dalam tubuhnya disebut orang phlegmatis. Kepribadian plegmatis secara umum bersifat introvert, pengamat, dan pesimis. Dalam Suryabrata (2008: 56), Kart menguraikan temperamen phlegmatis (orang dengan darah dingin), yaitu Phlegma berarti ketidaklembaman, jadi berarti tidak malas. Phlegma sebagai kelemahan ialah kecenderungan ke arah ketidakpekaan; alasan yang kuat tidak cukup untuk merangsangnya untuk bertindak; ketidakpekaan ini menyebabkan adanya kecenderungan ke arah kejemuan dan mengantuk. Phlegma sebagai kekuatan sebaliknya, merupakan sifat yang tidak mudah bergerak tetapi kalau sudah bergerak lalu tahan lama. Sifat-sifat khas golongan temperamen ini ialah:

a. Lambat menjadi panas, tetapi panasnya itu tahan lama,

b. Tidak mudah marah,

c. Darah yang dingin itu tak pernah dirisaukannya,

d. Cocok untuk tugas-tugas ilmiah.

\section{Menurut Anggo (2011:} 25), proses berpikir dalam pemecahan masalah merupakan hal penting yang perlu mendapat perhatian para pendidik terutama untuk membantu siswa agar dapat mengembangkan kemampuannya memecahkan masalah. Lebih lanjut keunggulan metode pemecahan masalah menurut Hamdani (2010: 84) yakni dapat melatih 
siswa berpikir dan bertindak kreatif serta merangsang perkembangan kemajuan berpikir siswa untuk menyelesaikan masalah yang dihadapi dengan tepat. Sesuai dengan pendapat Lester (dalam Anggo, 2011: 25) bahwa tujuan utama mengajarkan pemecahan masalah dalam matematika adalah tidak hanya untuk melengkapi siswa dengan sekumpulan keterampilan atau proses, tetapi lebih kepada memungkinkan siswa berpikir tentang apa yang dipikirkannya. Proses berpikir dalam penelitian ini adalah proses berpikir yang dilalui siswa ketika menyelesaikan masalah matematika pada materi aplikasi trigonometri.

\section{METODE PENELITIAN}

Penelitian ini dilaksanakan pada siswa kelas XII SMK Negeri 3 Metro semester genap Tahun Ajaran 2014/2015.Waktu penelitian merupakan lama penelitian yang berlangsung, dimulai dari tahap persiapan, pengambilan data sampai dengan tahap penyusunan laporan hasil penelitian. Waktu penelitian berlangsung sejak bulan November 2014 sampai Februari 2015.

Jenis penelitian ini adalah penelitian kualitatif deskriptif dikarenakan pada penelitian ini mendeskripsikan proses berpikir siswa SMK yang memiliki tipe kepribadian phlegmatis dalam menyelesaikan masalah matematika.

Subyek penelitian ini adalah SMK Negeri 3 Metro pada kelas XI Teknik Gambar Bangunan (TGB) semester ganjil tahun ajaran 2014/2015 sebanyak 3 orang siswa yang memiliki tipe kepribadian phlegmatis. Subyek penelitian diperoleh dari hasil test penggolongan tipe kepribadian.

Intrumen utama dalam penelitian ini adalah peneliti sendiri, dikarenakan peneliti mencari dan mengumpulkan data proses berpikir siswa secara langsung. Intrumen bantu dalam penelitian ini adalah soal matematika non rutin dalam bentuk essay.

Teknik pengumpulan data dalam penelitian ini menggunakan cara think aloud method, yaitu siswa diminta untuk menyelesaikan soal matematika yang disertai dengan ekspresi verbal terkait dengan jawaban yang tertera pada lembar jawaban. Langkah-langkah think aloud method yang digunakan, sebagai berikut:

1. Memilih 3 orang siswa yang memiliki tipe kepribadian phlegmatis. Masing-masing siswa akan menyelesaikan soal matematika pada waktu yang berbeda.

2. Memberikan soal matematika pada siswa. 
3. Meminta siswa untuk menyelesaikan masalah pada soal yang disertai dengan ekspresi verbal terkait jawaban yang tertera pada lembar jawaban.

4. Memberikan beberapa pertanyaan terkait dengan jawaban tertulis dan ekspresi verbal siswa.

5. Menggunakan alat bantu perekam.

6. Menganalisis hasil proses berpikir siswa pertama.

7. Melakukan pengambilan data pada siswa kedua dengan langkah yang sama dengan siswa pertama.

8. Menganalisis hasil proses berpikir siswa kedua.

9. Melakukan pengambilan data pada siswa ketiga dengan langkah yang sama dengan siswa pertama dan kedua.

10. Menganalisis hasil proses berpikir siswa ketiga.

11. Membandingkan hasil proses berpikir siswa pertama dengan kedua dan ketiga.

12. Menyimpulkan proses berpikir siswa.

Teknik analisis data dalam penelitian ini, sebagai berikut:

1. Mereduksi data proses berpikir yang tidak digunakan. Data akan digolongkan dalam kategori: memahami informasi, merencanakan penyelesaian,

melaksanakan

rencana

penyelesaian, dan meyakinkan kembali jawaban.

2. Menyajikan data dalam bentuk deskripsi pada masing-masing kategori untuk masing-masing siswa.

3. Menarik kesimpulan tentang proses berpikir siswa dengan tipe kepribadian phlegmatis.

Untuk mendapatkan data yang valid, dilakukan langkahlangkah sebagai berikut:

1. Mengambil data proses berpikir siswa pertama yang dilakukan dengan cara think aloud method.

2. Menganalisis data proses berpikir siswa pertama.

3. Mengambil data proses berpikir siswa kedua yang dilakukan dengan cara think aloud method.

4. Menganalisis data proses berpikir siswa kedua.

5. Mengambil data proses berpikir siswa ketiga yang dilakukan dengan cara think aloud method.

6. Menganalisis data proses berpikir siswa ketiga.

7. Membandingkan data proses berpikir siswa pertama dengan kedua dan ketiga.

8. Data dinyatakan valid apabila terdapat konsistensi pada data pertama, kedua, dan ketiga serta data tersebut menggambarkan proses berpikir siswa. 


\section{HASIL PENELITIAN DAN PEMBAHASAN}

Pengambilan data diawali dengan melakukan tes tipe kepribadian siswa pada hari Sabtu tanggal

November 2014.Berikut tabel hasil tes tipe kepribadian siswa:

\section{Tabel}

Hasil Tes Tipe Kepribadian

\begin{tabular}{|l|l|c|}
\hline No. & $\begin{array}{c}\text { Tipe } \\
\text { Kepribadian } \\
\text { Siswa }\end{array}$ & $\begin{array}{c}\text { Jumlah } \\
\text { Siswa }\end{array}$ \\
\hline 1. & Choleris & 1 \\
\hline 2. & Phlegmatis & 8 \\
\hline 3. & Melancholis & 6 \\
\hline 4. & Sanguinis & 6 \\
\hline \multicolumn{2}{|c|}{ Jumlah } & 21 \\
\hline
\end{tabular}

Pada penelitian ini dipilih 3 orang siswa yang memiliki tipe kepribadian phlegmatic sebagai subyek penelitian. Pemilihan subyek penelitian ini dilakukan dengan meminta pertimbangan guru matematika pada kelas XI TGB. Pertimbangan pemilihan subyek penelitian didasarkan pada kemampuan siswa untuk bisa mengungkapkan pemikirannya terkait dengan soal tes yang diberikan. Subyek penelitian diberikan 2 soal essay mengenai materi aplikasi trigonometri.

Pengambilan data yang pertama dilaksanakan pada hari senin tanggal 2 Februari 2015 pukul 13.00 s.d 14.00. pada pengambilan data pertama ini, ada hambatan yang terjadi dikarenakan pada saat itu sedang ada pelatihan senam disekolah sehingga suasana kurang kondusif. Pengambilan data kedua dilaksanakan pada hari senin tanggal 16 Februari 2015 dan pengambilan data yang ketiga pada tanggal 2 Maret 2015.Pengambilan data kedua dan ketiga berjalan dengan lancar.

Subyek 1

Subyek 1 dapat memahami masalah dan yang ditanyakan pada soal. Hal ini terlihat dari cuplikan hasil wawancara berikut:

Guru : Informasi apa yang ada di soal?

Siswa : Panjang tangga $8 \mathrm{~m}$ terus disandarkan ke dinding.

Guru : Dindingnya yang mana?

Siswa : Dindingnya ini.

Guru : OK, itu dinding. Terus, yang ditanya?

Siswa : Yang ditanya jarak, jarak kaki tangga ke dinding.

Guru : Yang mana?

Siswa : Ini.

Siswa dapat merencakan penyelesaian masalah, tetapi tidak dapat menjawab dengan tepat masalah pada soal. Selain itu subyek 1 juga tidak dapat menemukan cara agar penyelesaian lain yang dapat digunakan. Hal ini terlihat pada cuplikan hasil wawancara berikut:

Guru : Oh itu. Ok, sekarang udah dicoba itu pakai rumus apa? 
Siswa : Trigonometri.

Guru : Trigonometri pakai yang aturan apa?

Siswa : Pake cos.

Guru : Kenapa pakai cos?

Siswa : Soalnya perbandingannya samping sama miring.

Guru : Yang ditanya tadi yang mana?

Siswa: Ini, Jarak.

Samping.

Guru : Ok. Samping, ,makanya pakai

cos. Gak ada cara lain?

Siswa : Cara lain? Belum tau sih.

Subyek 2

Subyek2 dapat memahami masalah dan yang ditanyakan pada soal tanpa mengalami kesulitan.Berikut cuplikan wawancara:

Guru : Informasi apa yang ada di soal?

Siswa : Yang ditanya jarak B ke C.

Guru : Terus apa lagi? Selain yang ditanya apa aja?

Siswa : Diketahui panjang tangga itu kan 8m miringnya. Terus disandarkan pada dinding.Nah, membentuk sudut $60^{\circ}$.

Setelah memahami masalah, S2 selanjutnya merencakan dan menyelesaikan masalah dengan baik. Tetapi S2 tidak dapat menyelesaikan masalah dengan cara yang berbeda. Hal ini terlihat pada cuplikan wawancara berikut:
Guru : Kenapa pake cara itu?

Cos $60^{\circ}$ sama dengan $1 / 2$

$\sqrt{3}$. Kenapa

menggunakan cos?

Siswa : Karena kan cos itu sami. Kan kita mencari sa. Yang diketahui mi, miring. Jadi ya pakai cos.

Guru : Bisa dengan cara lain gak?

Siswa : Gak ada.

Guru : Kenapa gak ada?

Siswa : Ya..karena ini caranya seperti itu bu.

\section{Subyek 3}

Subyek 3 dapat memahami masalah dan mengetahui hal yang ditanyakan tanpa mengalami kesulitan. Hal ini terlihat dalam cuplikan wawancara berikut:

Guru : Informasi apa yang ada di soal?

Siswa : Panjang tangga.

Guru : Panjang tangga berapa?

Siswa : $8 \mathrm{~m}$.

Guru : Yang mana tangganya?

Siswa : yang disandarkan.

Guru : Terus?

Siswa : Sudutnya $60^{\circ}$ terhadap

tanah.

Guru : Mana sudutnya?

Siswa : Ini.

Guru : Ok itu. Terus yang

ditanya?

Siswa : Jarak kaki tangga.

Guru : Yang mana berarti?

Siswa : Ini, sisi AC.

Selanjutnya, S3 melakukan perencanaan penyelesaian dengan menggunakan rumus trigonometri. Tetapi S3 tidak dapat 
menyelesaikan masalah dengan cara yang berbeda. Hal ini terlihat dalam cuplikan wawancara berikut:

Guru : Sudah?Kenapa pakai rumus cos?

Siswa : Karena lebih enak Bu.

Guru : Kenapa lebih enak dengan cos?

Siswa: Karena yang diketahui ini kan sampingnya belum tapi miringnya kan sudah. Jadi kita bisa nyari C nya.Kan ini sudut $C$ jadi pakai samping ini biar ketemu Bu.

Guru : Coba dengan cara lain gimana?

Siswa : Dengan cara lain ya.

Guru : Bisa enggak dengan cara lain?

Siswa: kayaknya enggak Bu. Ya umpama pakai depan miring. Nah, yang kita cari kan yang C. Nanti kalau pakaui depan miring yang ketemu depannya yang ini enggak.

Data proses berpikir siswa dengan tipe kepribadian phlegmatic yang didapatkan, yaitu sebagai berikut.

1. Dapat memahami masalah dan yang ditanyakan pada soal tanpa mengalami kesulitan.

2. Dapat mengubah informasi pada soal kedalam bentuk matematika.
3. Dapat melakukan perencanaan penyelesaian dengan baik.

4. Tidak dapat menyelesaikan dengan cara yang berbeda.

Hasil analisis pada siswa phlegmatis sesuai dengan teori Tipologi Hippocrates-Galenus yang menyatakan bahwa tipe kerpibadian phlegmatis dalam menyelesaikan sebuah pekerjaan memiliki sifat, yaitu: cakap dan mantap, damai dan mudah sepakat, punya kemampuan administratif, menjadi penengah masalah, menghindari konflik, dan menemukan cara yang mudah. Selain itu, siswa dengan tipe kepribadian phlegmatis: kepribadian rendah hati, mudah bergaul dan santai, diam, tenang, sabar, baik keseimbangannya, hidup konsisten, tenang tetapi cerdas, simpatik dan baik hati, menyembunyikan emosi, dan bahagia menerima kehidupan.

\section{KESIMPULAN DAN SARAN}

Berdasarkan hasil penelitian dan pembahasan, dapat disimpulkan bahwa proses berpikir siswa dengan tipe kepribadian phlegmatic sebagai berikut.

1. Siswa dapat memahami masalah dan yang ditanyakan pada soal tanpa mengalami kesulitan. 
2. Siswa dapat mengubah informasi pada soal kedalam bentuk matematika.

3. Siswa dapat melakukan perencanaan penyelesaian dengan baik.

4. Siswa tidak dapat menyelesaikan dengan cara yang berbeda.

Berdasarkan kesimpulan di atas, maka disarankan sebagai berikut.

1. Dengan mengetahui proses berpikir siswa phlegmatic maka dalam pembelajaran guru hendaknya memberikan permasalahan yang lebih bervariasi sehingga siswa dapat menyelesaikan dengan cara yang berbeda.

2. Guru hendaknya memberikan metode pembelajaran yang variatif sehingga siswa memiliki kreativitas dalam memecahkan masalah.
Dewiyani. 2008. Mengajarkan Pemecahan Masalah Dengan Menggunakan Langkah Polya. Stikom Jurnal . Vol. 12, No 2, pp $87-95$.

Hamdani. 2010. Strategi Belajar Mengajar. Bandung: Pustaka Setia.

Sukmadinata, Nana Syaodih.2004. Landasan Psikologi Proses Pendidikan. Remaja Rosdakarya. Bandung.

Suryabrata, Sumadi. 2008. Psikologi Kepribadian. Raja Grafindo Persada. Jakarta.

\section{DAFTAR PUSTAKA}

Anggo, Mustamin. 2011. Pelibatan Metakognisi dalam PemecahanMasalah Matematika.Edumatica..ISS $N$ : 2088-2157.Vol.1, No.1, pp $25-32$. 